\title{
LA BÚSQUEDA DE RECONOCIMIENTO EN LA FORMACIÓN DE IDENTIDADES POLÍTICAS
}

\section{La posición ambigua frente a la modernidad occidental en América Latina y la construcción de la consciencia nacional}

\author{
H. C. F. Mansilla \\ Academia de Ciencias de Bolivia y Academia Boliviana de la Lengua
}

http://dx.doi.org/10.5209/rev_NOMA.2012.41766

\begin{abstract}
Resumen.- El texto utiliza la teoría del reconocimiento de Axel Honneth y los enfoques críticos en torno al romanticismo (como filosofía) para comprender la compleja relación de las sociedades latinoamericanos con la modernidad occidental. Enfoques románticos son percibidos como una temprana crítica clarividente de las alienaciones modernas. En América Latina tendencias románticas han servido también para revalorizar el pasado y las tradiciones propias frente al peso cultural de la modernidad occidental. La ensayística latinoamericana es vista como una respuesta muy interesante a la falta de reconocimiento de América Latina en el concierto de naciones. Pero algunas corrientes de la ensayística están bajo una influencia antiliberal y propenden a justificar regímenes populistas y autoritarios.
\end{abstract}

Palabras clave.- América Latina, antiliberalismo, discriminación, ensayística, reconocimiento, romanticismo

The Search of Recognition in the Formation of Political Identities. Latin America's Ambiguous Position facing Western Modernity and the Construction of National Consciousness

\begin{abstract}
The text is based on the recognition theory by Axel Honneth and on the critical analyses of romanticism (as a philosophy) in order to understand the complex relationship of Latin American societies with western modernity. Romantic conceptions are seen as an early and clairvoyant critique of modern alienations. In Latin America romantic tendencies have also served for revaluating the past and the own traditions in front of the cultural weight of western modernity. Latin American tradition of essays is perceived as a very interesting answer to Latin America's lack of recognition in the concert of nations. Some currents of the Latin American essays are, however, under antiliberal influence and are inclined to justify populist and authoritarian regimes.
\end{abstract}

Keywords.- antiliberalism, discrimination, essay, Latin America, recognition, romanticism 


\section{Las teorías del reconocimiento}

La segunda mitad del siglo XX nos ha mostrado varios fenómenos que pueden ser calificados como paradójicos. Los regímenes socialistas basados en el marxismo, con su pretensión de haber interpretado correctamente la historia y haber ejercido una praxis socio-política científica, se hundieron de forma irreparable en un lapso muy breve (19891991) y sin intervención externa. La independencia de las naciones africanas generó una ola de optimismo de enormes proporciones, que abarcaba tanto expectativas de progreso y prosperidad como la esperanza de un nuevo orden basado en la libertad y el Estado de derecho. Pero entre los resultados efectivos de ese proceso se hallan gobiernos despóticos, guerras civiles de considerable duración e intensidad y el agravamiento de la pobreza. Pese a innegables progresos en los campos económico e institucional, en América Latina han surgido experimentos populistas de indudable apoyo popular, que perpetúan tradiciones premodernas de vieja raigambre.

Por otra parte, el éxito de la democracia liberal y pluralista en los países del Norte ha sido empañado por la crisis financiera, los desarreglos ecológicos y el vacío existencial de amplio alcance, sobre todo en sectores juveniles de la población. Hoy en día no hay duda de que el cosmopolitismo liberal a ultranza no logra concitar emociones relevantes y fomenta, en cambio, el sentimiento que de la vida social es básicamente absurda. La prosperidad material y el buen funcionamiento de la maquinaria política no bastan para brindar sentido y contenido a la vida individual y colectiva. En este contexto se exhiben claramente las limitaciones del orden liberal-democrático: la gente no puede desplegar del todo sus facultades si no está enraizada en una vigorosa tradición cultural. Chantal Mouffe, una de las principales voces críticas con respecto al liberalismo, señala que los liberales no están en condiciones de reconocer la diversidad determinante de las identidades colectivas y el pluralismo sustancial del mundo social ${ }^{1}$. Tan indispensables como la vivienda y la alimentación resultan ser la familiaridad con los lazos primarios (como el lenguaje y las herencias histórico-culturales compartidas desde la niñez), la

1 Chantal Mouffe, Über das Politische. Wider die kosmopolitische Illusion (Sobre lo político. Contra la ilusión cosmopolita), Frankfurt: Suhrkamp 2007, p. 17. 
pertenencia a un grupo identificable y distinto de los demás y la comunicación espontánea con parientes y amigos. Sólo una comunidad primaria puede brindar la seguridad emocional y el reconocimiento primordial - exento del principio de rendimiento y desempeño - que pueden evitar las formas consuetudinarias de enajenación, soledad, desarraigo y autodesprecio individuales ${ }^{2}$. Los vínculos primarios y las tradiciones vivas tienen, por lo tanto, funciones positivas e indispensables para el desarrollo de consciencias individuales sólidas, funciones que no pueden ser reemplazadas por abstracciones como la ética universalista, las obligaciones contractuales, las estructuras burocráticoadministrativas y las organizaciones supranacionales, por más importantes y eficaces que estas también sean ${ }^{3}$. Esto tiene vigencia no sólo en el campo personal, sino también en el colectivo. Los individuos y las culturas se desarrollan de manera adecuada en la medida en que fortalecen su identidad, lo que ocurre en forma dinámica y dialógica en relación más o menos libre con otros ${ }^{4}$.

Es en esta constelación ${ }^{5}$ donde nacen las teorías contemporáneas del reconocimiento, cuyos representantes más ilustres son hasta el momento Charles Taylor ${ }^{6}$ y Axel Honneth. Ambos autores se adhieren a la magna concepción de G. W. F. Hegel: el reconocimiento es la relación ideal y recíproca entre sujetos que se perciben el uno al otro como iguales y, al mismo tiempo, como diferentes. Este vínculo es constitutivo para la formación de la subjetividad, sobre todo en la era moderna. Uno se convierte en sujeto individual cuando reconoce a otro sujeto en su pleno derecho y sus posibilidades y cuando es reconocido como tal por este último. Esta tesis hegeliana está opuesta al liberalismo individualista clásico porque presupone que los nexos sociales existen antes que los individuos; la intersubjetividad tendría prioridad sobre la subjetividad ${ }^{7}$. Honneth va más allá y postula que el amor al otro y el ser amado por el otro constituyen las precondiciones para la participación en la vida pública de una comunidad; este contexto debe ser ampliado necesariamente por una dimensión que abarca la solidaridad efectiva y la apreciación

2 Isaiah Berlin, The Counter-Enlightenment, en: Isaiah Berlin, Against the Current. Essays in the History of Ideas, Londres: Hogarth 1980, pp. 1-24, especialmente pp. 10-14.

3 Cf. la obra clásica, con notable material empírico: Richard Sennett / Jonathan Cobb, The Hidden Injuries of Class, New York: Knopf 1972.

4 Cf. la obra fundamental: Axel Honneth, Kampf um Anerkennung. Zur moralischen Grammatik sozialer Konflikte (La lucha por el reconocimiento. Sobre la gramática moral de los conflictos sociales), Frankfurt: Suhrkamp 1992, passim. Cf. también: Sebastián Kaufmann, Multiculturalidad y ética del reconocimiento, en: PERSONA Y SOCIEDAD (Santiago de Chile), vol. XXV, № 1, abril de 2011, pp. 75-87, especialmente p. 86.

5 Cf. la gran obra pionera en este campo: Barrington Moore, Injustice: The Social Bases of Obedience and Revolt, White Plains: Sharpe 1978.

6 Charles Taylor, El multiculturalismo y la "política del reconocimiento", Madrid: FCE 2003; Charles Taylor, Dilemmas and Connections: Selected Essays, Cambridge: Harvard U. P. 2011.

7 Cf. el brillante resumen en: Nancy Fraser, Soziale Gerechtigkeit im Zeitalter der Identitätspolitik. Umverteilung, Anerkennung und Beteiligung (Justicia social en la era de la política de la identidad. Redistribución, reconocimiento y participación), en: Nancy Fraser / Axel Honneth, Umverteilung oder Anerkennung? Eine politisch-philosophische Kontroverse (¿Distribución o reconocimiento? Una controversia político-filosófica), Frankfurt: Suhrkamp 2003, pp. 13-128, especialmente p. 19. 
positiva $^{8}$. Entre las consecuencias prácticas de este postulado se halla en primer lugar la autorrealización de la comunidad respectiva: el autodespliegue de sus potencialidades intrínsecas. La moral colectiva y las políticas afines a las concepciones de estos autores representan una ventaja con respecto a las liberales porque admiten las diferencias sociales, étnicas y culturales y las tratan con respeto, por un lado, y con la intención de fomentar su consolidación y crecimiento, por otro ${ }^{9}$. Es decir: mediante la teoría y la praxis del reconocimiento se dejaría atrás la concepción formalista de justicia, derivada del acatamiento procedimental y del respeto a estatutos contractuales. Se puede decir que la teoría de Axel Honneth acerca del reconocimiento es una complementación actualizada de las doctrinas morales universalistas - como la kantiana y la que se puede inferir del corpus teórico de la Escuela de Frankfurt -, mediante la inclusión de los aspectos derivados de la intersubjetividad.

Al tomar en serio la diversidad cultural, los enfoques de Taylor y Honneth - y las políticas correspondientes - promueven ante todo la identidad de aquellos sujetos que, por diversas causas, requieren de un reconocimiento público manifiesto y duradero. Para estos pensadores, genética y conceptualmente el reconocimiento intersubjetivo tiene preferencia sobre el conocimiento racional-intelectual, lo cual posee claras reminiscencias románticas. La compasión y el interés por el otro, por ejemplo, poseen primacía sobre el tratamiento correcto pero frío de las burocracias estatales. De acuerdo con Honneth, la cosificación en cuanto alienación - el fenómeno negativo más usual en el mundo moderno - es un olvido premeditado del reconocimiento ${ }^{10}$.

La política del reconocimiento está encauzada a un mundo favorable a las diferencias, en el cual el principio liberal de la igualdad y la práctica jurídica del tratamiento uniforme no deben significar una asimilación obligatoria del individuo o del grupo a las normas mayoritarias ni tampoco una renuncia a los propios elementos identificatorios de vieja data. Según Honneth, se trata de otorgar ayuda y protección moral a los grupos e individuos que pueden ser calificados como únicos o como heterogéneos con respecto a una mayoría social, para lo cual se necesita una especie de sensibilidad similar a la estética, impregnada de empatía y de la capacidad de identificarse con el otro ${ }^{11}$. Para Honneth la inclusión social se basa primeramente en la experiencia elemental del reconocimiento fundamental de los individuos y grupos por el conjunto social, y sólo

\footnotetext{
8 Axel Honneth, Kampf..., op. cit. (nota 4), pp. 65-68, 73.

9 Sobre el aporte de Charles Taylor a esta temática cf. Ingeborg Breuer, Charles Taylor zur Einführung (Introducción a Charles Taylor), Hamburgo: Junius 2000, pp. 133-142.

10 Axel Honneth, Verdinglichung. Eine anerkennungstheoretische Studie (Cosificación. Un estudio en la teoría del reconocimiento), Frankfurt: Suhrkamp 2005, p. 45, 62.

11 Axel Honneth, Das Andere der Gerechtigkeit. Habermas und die ethische Herausforderung der Postmoderne (Lo otro de la justicia. Habermas y el desafío ético de la postmodernidad), en: Honneth, Das Andere der Gerechtigkeit. Aufsätze zur praktischen Philosophie (Lo otro de la justicia. Ensayos sobre filosofía práctica), Frankfurt: Suhrkamp 2000, pp. 133-170, aquí p. 147.
} 
posteriormente en la participación en los procesos de formación de opiniones y voluntades políticas. Siguiendo a Jürgen Habermas, Honneth cree que "lo Otro" de la justicia es la solidaridad, concebida como la participación efectiva en el destino existencial de otra persona; el propio autor admite el carácter utópico y abstracto de este postulado en la inmensa mayoría de los $\operatorname{casos}^{12}$. De todas maneras: los derechos y las regulaciones de origen liberal no satisfacen plenamente las necesidades de reconocimiento que se derivan de la vulneración de la propia integridad, el honor y la dignidad. La injusticia social es en primer término percibida como humillación y desprecio, es decir como un problema existencial y moral, y recién en segundo lugar como un asunto económico (concerniente a la redistribución de ingresos) ${ }^{13}$. Según Honneth hay tres esferas en las que ocurren los fenómenos de reconocimiento: el campo del amor, la esfera jurídica del tratamiento igualitario y el campo de la apreciación social (determinado este último por el principio de rendimiento y desempeño) ${ }^{14}$.

La teoría de Axel Honneth (y similares) ha sido criticada por producir una reducción de la sociología política a la psicología moral, por sobrevalorar la superestructura del reconocimiento social inmersa en el sistema capitalista y por limitar la justicia social dentro de un contexto de identidades y asuntos afines. El sufrimiento individual y grupal producido por la falta de reconocimiento es muy a menudo un fenómeno prepolítico que no puede ser amortiguado o compensado por políticas públicas, por más diferenciadas que estas sean. La teoría del reconocimiento conlleva, sobre todo, una expansión inadecuada de la esfera cultural, que corresponde a un menoscabo de la dimensión económica y a una pérdida de significación de las luchas por la redistribución de bienes e ingresos ${ }^{15}$. Por otra parte, desde la perspectiva liberal, hay que señalar que la teoría de Honneth se basa, en el fondo, en una presunción de igualdad liminar entre los seres humanos - que habría que "reconocer" mediante procedimientos muy sofisticados, aunque sea en la ficción de oportunidades equiparables para todos -, igualdad que no existe en las sociedades altamente diferenciadas y complejas de la actualidad y que obstaculizaría la competencia entre los humanos, el espíritu de innovación y la pluralidad de opciones de vida.

La teoría del reconocimiento es importante para comprender la construcción de las consciencias nacionales en América Latina y, por lo tanto, la formación de identidades políticas de amplio alcance. Este enfoque teórico estuvo concebido originalmente para

12 Ibid., pp. 168-169.

13 Axel Honneth, Umverteilung als Anerkennung. Eine Erwiderung auf Nancy Fraser (Distribución como reconocimiento. Una réplica a Nancy Fraser), en: Nancy Fraser / Axel Honneth, op. cit. (nota 7), pp. 129-224, aquí pp. 155-156.

14 Ibid., p. 162, 213.

15 Nancy Fraser, Anerkennung bis zur Unkenntlichkeit verzerrt. Eine Erwiderung auf Axel Honneth (El reconocimiento desfigurado hasta lo irreconocible. Una réplica a Axel Honneth), en: Nancy Fraser / Axel Honneth, op. cit. (nota 7), pp. 225-270, especialmente p. 232, 248, 264. 
comprender la situación de personas y grupos en el seno de conjuntos sociales, pero puede ser ampliado a pueblos y naciones en el concierto internacional. Desde comienzos del siglo XIX ha existido en el Nuevo Mundo un sentimiento muy dilatado de falta de estima y apreciación equitativa de parte de los otros países soberanos, sobre todo del llamado ámbito metropolitano conformado por Europa Occidental y América del Norte. Los vínculos estructurales entre el mundo ya desarrollado y el bloque latinoamericano han estado marcados por la asimetría y la desigualdad. Las sociedades menos favorecidas, como las latinoamericanas, han percibido esta constelación desde el primer momento como un contexto de injusticia e inequidad. Se ha dado desde entonces una larga sumatoria de agravios, que paulatinamente ha pasado del plano político y cultural al terreno de la economía y el comercio. Aun sin ingresar a una valoración de estos nexos, no hay duda del sentimiento colectivo de discriminación secular que prevalece individual y nacionalmente en las mentalidades latinoamericanas. Es entonces comprensible que hayan surgido varias estrategias políticas e intelectuales, basadas en la reivindicación de las diferencias, para paliar esas relaciones vistas como injustas y para construir una sólida consciencia social fundamentada en el orgullo de lo que es propio. En este camino ha sido inevitable una revalorización del pasado de las sociedades latinoamericanas, sobre todo en aquellas que han tenido grandes civilizaciones precolombinas. La idealización y el embellecimiento romántico de aquellos tiempos es el producto forzoso de esta operación intelectual. Por ello es conveniente echar un vistazo a las concepciones que tratan de hacer justicia a las diferencias culturales, como la teoría del reconocimiento y las variantes del comunitarismo.

La teoría del reconocimiento de Axel Honneth es algo muy distinto de las doctrinas que enaltecen acríticamente las diferencias culturales. Pero sus aspectos flacos pueden ser fácilmente advertidos si consideramos por un momento las carencias inherentes al particularismo convencional, al comunitarismo teórico ${ }^{16}$ y al relativismo contemporáneo, sobre todo en lo referente a la praxis política cotidiana. Estas corrientes pueden exacerbar sentimientos nacionalistas y tendencias irracionalistas. Pueden contribuir a diluir las grandes contribuciones de la llustración y el racionalismo europeos, a aumentar las discrepancias entre los grupos étnicos, a magnificar las diferencias entre los individuos y a entorpecer el entendimiento entre sociedades y también entre los hombres. Valores particulares, en primera instancia los nacionales, pierden fácilmente su característica de meras señas de identidad, iguales o, por lo menos, comparables a las de los otras naciones, y se transforman en cualidades sagradas, mejores y más respetables que las de los vecinos y de todos los otros pueblos. Simples peculiaridades identificatorias, sin las cuales no puede vivir ningún individuo y ninguna comunidad, se convierten en evidencias de la propia superioridad sobre los otros, superioridad que a veces debe ser demostrada en los terrenos de la economía, la política y la guerra. La exaltación de la identidad - lo

16 Cf. Jefferson Jaramillo Marín, Las metáforas de lo comunitario. A propósito de una lectura crítica sobre el sentido de lo comunitario en la óptica de Zygmunt Baumann, en: REFLEXIÓN POLÍTICA (Bucaramanga), vol. 9, No 18, diciembre de 2007, pp. 20-31. 
propio y particular - hace olvidar el origen común de todos los grupos humanos, sobre lo cual se basa todo humanismo religioso y secular. En casos extremos, que no son raros en la historia de la humanidad, este ensalzamiento particularista permite percibir a cualquier persona y a pueblos enteros como desprovistos de características humanas, es decir como seres inferiores que pueden ser utilizados y hasta asesinados sin remordimientos. Como Isaiah Berlin aseveró, las formas extremas de particularismo terminan en la barbarie $^{17}$. En el campo político las concepciones comunitaristas pueden favorecer la sobreprotección y la sobrerrepresentación de minorías que tienen la suerte o la fuerza momentánea de hacerse oír efectiva y enérgicamente. El resultado es el privilegiamiento convencional y rutinario de un grupo (por ejemplo en la América Latina de hoy: un movimiento social agresivo) en detrimento de otros.

Finalmente es de justicia señalar que la teoría de Axel Honneth nunca abandona la alta esfera de la teoría pura; por ello resulta demasiado general y abstracta, y a veces exhibe rasgos de idealismo e ingenuidad en torno a los móviles e intereses de los hombres en su accionar cotidiano. No hay duda de que las grandes obras del teatro, el cine y la literatura han tratado el tema del reconocimiento y los conflictos morales derivados del mismo de una manera más realista y más diferenciada.

\section{El romanticismo como crítica clarividente de las alienaciones modernas}

A comienzos del siglo XIX surgió el romanticismo como oposición a lo que era percibido como la prepotencia del racionalismo y la llustración, es decir como contraposición filosófica y literaria a lo que entonces ya se había convertido en clásico. Lo romántico era también un renacimiento de los sentimientos frente al frío cálculo utilitario, una revigorización de las tradiciones nacionales y locales, independientemente de que estas fueran irracionales y antidemocráticas. Era una comprensible propensión anticosmopolita, en una época en que el racionalismo francés - apoyado por los ejércitos napoleónicos pretendía imponer al mundo una sola forma de organización política y cultural. La era histórica que se inicia con la Revolución Francesa y la industrialización ha sido considerada no sólo como el advenimiento del reino de la razón y la democracia, sino también como la época de la deshumanización masiva, signada sobre todo por la prevalencia de la racionalidad instrumental, el principio de rendimiento y eficacia y la omnipotencia del dinero en cuanto criterio universal y universalizador. Según Axel Honneth, pensadores de muy diversas tendencias, como Theodor W. Adorno y Michel Foucault, creyeron ver a partir de 1800 un interminable tiempo histórico, en el cual la

17 Isaiah Berlin, Der angebliche Relativismus des europäischen Denkens im 18. Jahrhundert (El presunto relativismo del pensamiento europeo en el siglo XVIII), en: Isaiah Berlin, Das krumme Holz der Humanität. Kapitel der Ideengeschichte (El árbol torcido de la humanidad. Capítulos de la historia de las ideas), Frankfurt: Fischer 1992, pp. 97-122, especialmente p. 102; Berlin, Die europäische Einheit und ihre Wechselfälle (La unidad europea y sus altibajos), en: ibid., pp. 222-259, aquí p. 228. 
ideología humanista, los nuevos códigos jurídicos y el impulso uniformador de la Ilustración encubren un saber instrumental que sirve, sobre todo, a la consolidación del poder político ${ }^{18}$.

Como afirmó Honneth en un brillante texto, el "romanticismo anticapitalista" (o "anticapitalismo romántico") representó la base para una crítica incisiva de la modernidad con un evidente giro utópico ${ }^{19}$. La existencia perentoria de un desgarramiento del individuo y un desmembramiento del ámbito social - en cuanto los fenómenos sociales prevalecientes de la época -, que creen constatar los intelectuales románticorevolucionarios, presupone que anteriormente se habría dado una "unidad orgánica" de la persona con el entorno social y consigo misma, unidad que los románticos querían reconstituir mediante la acción colectiva o por medio de las experiencias místico-literarias del individuo. Los jacobinos radicales, los literatos conservadores y los marxistas han sido influidos por el romanticismo en diverso grado, aunque algunos de ellos siempre se han reclamado de un enfoque científico. En América Latina esta corriente tuvo su notable peso a lo largo del siglo XIX y a comienzos del XX.

De acuerdo con Honneth, el fenómeno del desgarramiento es experimentado en tres planos: (1) la persona con respecto a su propio yo, (2) el individuo con referencia a la sociedad y (3) la humanidad en relación con la naturaleza ${ }^{20}$. Según la terminología marxista se trata de fenómenos de alienación de muy diversas características, pero que pueden ser subsumidos en la incapacidad del individuo bajo el capitalismo de desplegar libremente sus posibilidades y talentos; la capacidad del ser humano de expresar sus necesidades y de realizar sus potencialidades es coartada por un régimen socioeconómico inhumano que busca exclusivamente la generación de una ganancia materialista de corto plazo. Los románticos, por su parte, ven el ideal de autorrealización individual y colectivo en la actividad espontánea y creadora del artista. Se trata, evidentemente, de una utopía esteticista, que subyace asimismo a la visión normativa marxista de un orden social perfecto, exento de las alienaciones del orden capitalista, visión que fue tematizada en los tempranos escritos filosóficos de Karl Marx.

Pero no sólo pensadores revolucionarios sostuvieron que el capitalismo y su factor más

18 Axel Honneth, Foucalt und Adorno. Zwei Formen einer Kritik der Moderne (Foucault y Adorno. Dos formas de una crítica de la modernidad), en: Axel Honneth, Die zerrissene Welt des Sozialen. Sozialphilosophische Aufsätze (El mundo desgarrado de lo social. Ensayos filosófico-sociales), Frankfurt: Suhrkamp 1999, pp. 73-92, aquí pp. 84-85.

19 Axel Honneth, Eine Welt der Zerrissenheit. Zur untergründigen Aktualität von Lukács' Frühwerk (Un mundo del desmembramiento. Sobre la actualidad subterránea de la obra temprana de Lukács), en: Axel Honneth, Die zerrissene..., op. cit. (nota 18), pp. 9-24, especialmente pp. 11-15; cf. también Isaiah Berlin, Die Apotheose des romantischen Willens. Die Revolte gegen den Mythos einer idealen Welt (La apoteosis de la voluntad romántica. La revuelta contra el mito del mundo ideal), en: Isaiah Berlin, Das krumme Holz..., op. cit. (nota 17), pp. 260-296.

20 Axel Honneth, Eine Welt..., op. cit. (nota 19), p. 11. 
visible - el trabajo convertido en una simple mercancía - estropeaban la auténtica vida individual y social; los partidarios del orden precapitalista en sus muchas variantes, los inspirados por el mensaje evangélico y los entusiastas de los modelos civilizatorios en el Nuevo Mundo previos a la conquista española han creído sinceramente en el valor paradigmático supremo de las utopías anteriores a la caída del ser humano en los meandros perversos de la división del trabajo y del predominio del dinero. Se trata, manifiestamente, de una concepción con elementos religiosos y mesiánicos, que se ha expandido sintomáticamente con el advenimiento del capitalismo y sus desventajas. En cierta medida casi todos los críticos del capitalismo y la modernidad han compartido y comparten una nostalgia muy noble, pero empíricamente no comprobable, de que alguna vez hubo una Edad de Oro de la evolución de nuestra especie, en la cual el Hombre conformaba una unidad consigo mismo, con su entorno social y con la naturaleza. En aquella época el mundo laboral y la esfera socio-política habrían estado exentos de los factores de alienación. Esta utopía de lo perfecto, aunque haya existido tal vez en un grado muy elemental y hasta nebuloso de desarrollo histórico, ha dado pie desde tiempos muy antiguos a un paradigma muy difundido de organización humana, el modelo por excelencia de convivencia razonable, que constituye el criterio con (o contra) el cual se juzga la calidad de los regímenes sociales realmente existentes. La Edad Media para los románticos europeos y el ámbito precolombino para los indigenistas latinoamericanos representan esos dechados de virtudes colectivas y morales, que ahora se echan en falta. Es probable que la unidad del ser humano consigo mismo, con la sociedad y la naturaleza represente una idea muy noble de la fantasía humana, imposible después del Neolítico, que ha sido seguramente la revolución social más importante de nuestro desarrollo y la que nos alejó definitivamente de una concordia liminar con el orden natural. Pero aun así y en casi todas las culturas la imagen de la Edad de Oro es importante como crítica y correctivo de nuestra evolución posterior, tan pobre en genuinas satisfacciones y logros positivos.

En las concepciones de Karl Marx, Georg Lukács y la Escuela de Frankfurt aparece esta figura de un mundo libre de alienaciones como impulso ético e intelectual para criticar la racionalidad instrumental. Bajo un claro tinte romántico, el dominio sobre la naturaleza es considerado como el paso primordial hacia el distanciamiento del Hombre con respecto a sí mismo. La pérdida del espontaneísmo sensorial, el disciplinamiento de la vida de los instintos, la división del trabajo y la instauración de los órganos del poder político serían las etapas inexorables para establecer el mundo moderno de la cosificación y la explotación del Hombre por el Hombre ${ }^{21}$. Y también se puede pensar que imágenes similares, tomadas del ámbito precolombino (o mejor dicho: atribuidas al mismo por autores contemporáneos), han sido centrales para que los ensayistas latinoamericanos construyan su visión idealizada de un mundo exento de alienaciones y, por lo tanto, normativo para

21 Cf. la exposición de esta temática en: Axel Honneth, Kritische Theorie. Vom Zentrum zur Peripherie einer Denktradition (Teoría crítica. Del centro a la periferia de una corriente del pensamiento), en: Honneth, Die zerrissene..., op. cit. (nota 18), pp. 25-73, aquí. p. 42. 
concebir soluciones alternativas con respecto a la pobreza material y espiritual del orden capitalista contemporáneo. De manera análoga al taller del artista en el Renacimiento o a la colectividad campesina rusa, se cree que el orden social en el imperio incaico o en el azteca permitía que el ser humano experimentase una comunión ejemplar consigo mismo, con la sociedad y la naturaleza. Hoy en día el romanticismo, en un sentido amplio, también puede ser considerado como la desaprobación de las poderosas corrientes occidentales en el terreno de la organización institucional y también como el rechazo de las prácticas y los intereses liberal-capitalistas, los cuales - en el ámbito hispano-católico - se enfrentaron desde un comienzo a una fuerte animadversión religiosa y social, teñida de crítica estetizante cultural y literaria.

El vigoroso renacimiento de ideologías indigenistas e indianistas ${ }^{22}$ en las últimas décadas se basa parcialmente en una visión romántica y edulcorada de las comunidades aborígenes del Nuevo Mundo. En la obra de Guillermo Bonfil Batalla, de notable ascendiente en México, América Central y en el área andina, encontramos tres aspectos reiterativos de esta concepción: (a) Antes de la llegada de los europeos existió en estas tierras una sola civilización y una correspondiente unidad política; (b) ese modelo civilizatorio estaba fundamentado en valores como la solidaridad, la honradez y la sobriedad, mientras que la cultura "invasora" occidental se orientaba (y se orienta) por el odio, el egoísmo y el "apetito insaciable de bienes materiales"; y (c) como solución a los problemas contemporáneos es postulada una "necesaria negación de occidente", presuponiendo que ella per se es la mejor alternativa a la evolución actual de las sociedades latinoamericanas en campos tan diferentes como la ética social, la organización económica y la protección al medio ambiente ${ }^{23}$. Apoyado en estos conceptos, cuya función de justificación doctrinaria es manifiesta, el gobierno populista boliviano a partir de enero de 2006 pretende encarnar la "reserva moral de la humanidad", por el mero hecho de que el presidente es un indígena que, de acuerdo a la propaganda oficial, aun personificaría las antiguas virtudes del orden precolombino. Las tendencias indigenistas e indianistas, las cuales ostentan un claro ímpetu romántico-reivindicacionista, se basan en muy escasos vestigios de transmisión oral para sustentar complejas teorías actuales en torno a la identidad de las naciones precolombinas y sus creaciones intelectuales y hasta filosóficas ${ }^{24}$. Los elementos estructurantes de aquellas civilizaciones habrían, por ejemplo, alimentado sistemas de solidaridad inmediata, por un lado, y

22 Sobre la diferencia entre indigenismo e indianismo cf. José Alcina Franch, El indianismo de Fray Bartolomé de Las Casas, en: José Alcina Franch (comp.), Indianismo e indigenismo en América, Madrid: Alianza 1990, pp. 34-44, especialmente p. 38.

23 Guillermo Bonfil Batalla, Aculturación e indigenismo: la respuesta india, en: José Alcina Franch (comp.), op. cit. (nota 22), pp. 189-209, aquí p. 194, 197, 199.

$24 \quad$ La carencia de fuentes escritas aborígenes impide establecer claramente dos elementos que son habitualmente el comienzo del quehacer filosófico en sentido crítico: (1) la facultad, así sea incipiente, de poner en cuestionamiento lo obvio y sobreentendido de las propias creencias y (2) la reflexión en torno a los desafíos que supone la existencia de las comunidades externas. 
prácticas pro-ecológicas y conservacionistas, por otro, que deberían ser consideradas aun hoy como modélicas por las sociedades contemporáneas ${ }^{25}$.

Es de justicia mencionar los aspectos positivos y promisorios de estas concepciones. Al romanticismo se debe la superación de una concepción simple y lineal de la historia, por una parte, y la preocupación concomitante por los aspectos aparentemente marginales y secundarios de la evolución humana, por otra. El notable interés dedicado a la Edad Media y a fenómenos religiosos que trajeron consigo las visiones románticas a comienzos del siglo XIX ha sido complementado por el estudio por lo fragmentario y lo curioso, lo escondido y lo repelido, lo lateral y lo secundario. Estos factores, desatendidos premeditadamente por las escuelas racionalistas, recobran su valor como posibilidades de acceso al conocimiento histórico-social tan válidas como los "grandes" temas del desarrollo. De acuerdo a concepciones muy posteriores inspiradas por intuiciones provenientes del romanticismo - como la Escuela de Frankfurt -, la preocupación por lo fragmentario se revela a menudo como una alternativa teórica altamente productiva ${ }^{26}$.

Uno de los grandes méritos del romanticismo ha sido redescubrir la relevancia de lo presuntamente excéntrico, la importancia de las fracturas histórico-culturales (paralelamente a las continuidades del mismo tipo) y la significación profunda de lo nointegrado, es decir de aquello que no emerge prima facie como factor central en los análisis evolutivos. Un ejemplo de este enfoque es la obra de Walter Benjamin, que, como se sabe, anticipó el posterior despliegue crítico-teórico de la Escuela de Frankfurt ${ }^{27}$. La teoría de Theodor W. Adorno - asistemática por excelencia - puede ser considerada (a) como el esfuerzo incesante de hacer justicia a lo no-idéntico, a lo específico y particular, a lo complejo, heterogéneo y disperso ${ }^{28}$ y (b) como la crítica continua del principio de identidad, que estaría también inmerso en los grandes sistemas dialécticos, como el de $\mathrm{G}$. W. F. Hegel, y que, en general, sería inseparable de la voluntad de poder y del ansia de

25 Cf. los testimonios tempranos: Ramiro Condarco Morales, Historia del saber y la ciencia en Bolivia, La Paz: Academia Nacional de Ciencias de Bolivia 1978, pp. 23-35; Manuel Sarkisyanz, Kollasuyo: indianische Geschichte der Republik Bolivien. Propheten des indianischen Aufbruchs (Kollasuyo: historia india de la República de Bolivia. Los profetas del levantamiento indio), Idstein: Schulz-Kirchner 1993.

${ }_{26}$ Helmut Dubiel, Kritische Theorie der Gesellschaft. Eine einführende Rekonstruktion von den Anfängen im Horkheimer-Kreis bis Habermas (La teoría crítica de la sociedad. Una reconstrucción introductora desde los comienzos en el círculo de Horkheimer hasta Habermas), Weinheim / Munich: Juventa 1988, p. 15.

27 Jürgen Habermas, Vorwort (Prólogo), en: Jürgen Habermas, Politik, Kunst, Religion. Essays über zeitgenössische Philosophen (Política, arte, religion. Ensayos sobre filósofos contemporáneos), Stuttgart: Reclam 1978, pp. 3-10, aquí p. 6; Jürgen Habermas, Vorwort (Prólogo), en: Jürgen Habermas, Philosophisch-politische Profile (Perfiles filosófico-políticos), Frankfurt: Suhrkamp 1987, pp. 9-13, aquí p. 11.

28 Theodor W. Adorno, Zur Metakritik der Erkenntnistheorie. Studien über Husserl und die phänomenologischen Antinomien (Metacrítica de la teoría del conocimiento. Estudios sobre Husserl y las antinomias fenomenológicas), Stuttgart: Kohlhammer 1956, pp. 13, 18-19, 29; Theodor W. Adorno, Drei Studien zu Hegel (Tres estudios sobre Hegel), Frankfurt: Suhrkamp 1963, pp. 164-165. 
dominación ${ }^{29}$. Adorno afirmó que según un impulso enfáticamente crítico, la filosofía debería ser "la consciencia consecuente de la no-identidad"30.

La revalorización de los particularismos nacionales está asociada al romanticismo del siglo XIX y a ciertas doctrinas conservadoras y hasta irracionalistas. Los románticos afirmaron que las grandes corrientes homogeneizadoras han aplastado la heterogeneidad de los pueblos y el pluralismo civilizatorio, destruyendo así el carácter de hogar familiar que habían tenido previamente las comunidades políticas premodernas. De acuerdo con Axel Honneth, uno de los méritos principales del romanticismo ha consistido en descubrir el valor ético de la pertenencia cultural de cada individuo y grupo, lo que conformaría un adecuado polo opuesto al frío "racionalismo monista" de la llustración clásica ${ }^{31}$.

El romanticismo, sobre todo el influido por concepciones radicales, ha tenido asimismo la virtud de señalar lo rescatable (definido social e históricamente) que se halla en el núcleo humanista de las grandes religiones. Desde una perspectiva muy diferente, la de la ética discursiva, Jürgen Habermas admitió que los credos religiosos han mantenido vigente una "consciencia de lo que falta", es decir un impulso de solidaridad con los débiles y de justicia social sin mediaciones institucionales ${ }^{32}$. Habermas vislumbró esa consciencia de carencias en los fundamentos prepolíticos que anteceden y subyacen a la formulación de las grandes teorías e ideologías políticas. Efectivamente: en la religiosidad popular, como creen los románticos, se han conservado de forma intensa y emotiva esas nociones de fraternidad y justicia, aunque sea de un modo conceptualmente poco claro. También es verdad que estos ideales no han merecido la atención prioritaria de las corrientes racionalistas y menos de las doctrinas liberales. Por otra parte, las concepciones de solidaridad y justicia han representado una preocupación permanente del pensamiento latinoamericano que se halla cerca de presupuestos románticos, del cual se puede mencionar algunas tendencias de la Teología y Filosofía de la Liberación.

29 Theodor W. Adorno, Negative Dialektik (Dialéctica negativa), Frankfurt: Suhrkamp 1966, pp. 149, 172, 266, 309-310; sobre la relación entre el principio de identidad y la voluntad de poder cf. Thomas Mirbach, Kritik der Herrschaft. Zum Verhältnis von Geschichtsphilosophie, Ideologiekritik und Methodenreflexion in der Gesellschaftstheorie Adornos (La crítica del poder. Sobre la relación entre filosofía de la historia, crítica de las ideologías y reflexión metodológica en la teoría social de Adorno), Frankfurt: Campus 1979, pp. 16-19.

30 Theodor W. Adorno, Negative Dialektik, op. cit. (nota 29), p. 15; Adorno, Drei Studien zu Hegel, op. cit. (nota 28), p. 119.

31 Axel Honneth, Zwischen negativer Freiheit und kultureller Zugehörigkeit. Eine ungelöste Spannung in der politischen Philosophie Isaiah Berlins (Entre la libertad negativa y la pertenencia cultural. Una tensión no resuelta en la filosofía política de Isaiah Berlin), en: Honneth, Das Andere..., op. cit. (nota 11), pp. 310-327, aquí p. 311.

32 Jürgen Habermas, Ein Bewusstsein von dem, was fehlt (Una consciencia de lo que falta), en: Michael Reder / Josef Schmidt (comps.), Ein Bewusstsein von dem, was fehlt. Eine Diskussion mit Jürgen Habermas (Una consciencia de lo que falta. Una discusión con Jürgen Habermas), Frankfurt: Suhrkamp 2008, pp. 2636, aquí pp. 31-32; Habermas, Eine Replik (Una réplica), en: ibid., pp. 94-107, especialmente p. 95, 104. 
La inclusión de diversas teorías de origen latinoamericano bajo el rubro del romanticismo es posible porque concepciones asociadas a este último

(a) han revalorizado positivamente las diferencias de país a país y de periodo a periodo y no las han subsumido bajo una secuencia evolutiva obligatoria y nivelizadora;

(b) han sido partidarios de la revitalización de un pasado rico y diverso, que sólo ante los ojos de doctrinas occidentales poco informadas podría ser considerado como deficiente y estéril; y

(c) han llamado tempranamente la atención acerca de la destrucción ecológica causada por la urbanización acelerada y la industrialización contaminante ${ }^{33}$ y se han preocupado por preservar el entorno natural, amenazado por las consecuencias prácticas de la razón modernizadora ${ }^{34}$.

No hay duda de que el "progreso" material en tierras latinoamericanas, sobre todo en la región andina, ha destruido los vínculos primarios y ha diluido las certezas doctrinarias de la población rural y al mismo tiempo no ha creado valores compensatorios adecuados que ofrezcan a las poblaciones desarraigadas las certidumbres del mundo premoderno. En esta constelación es comprensible que surjan impulsos de amplia aceptación popular en contra del cosmopolitismo liberal y del universalismo racionalista, impulsos que contienen elementos del romanticismo anticapitalista y que, lamentablemente, significan también un retorno a normas y prácticas autoritarias y antidemocráticas.

Finalmente hay que indicar que una de las fuentes de la vigencia permanente de la crítica romántica a los procesos de modernización y democratización liberal en América Latina reside, lamentablemente, en una visión unilateral y negativa de los resultados prácticos de esos procesos. Esta popular visión se basa, de modo paradójico, en cerrarse a toda percepción de los aspectos positivos que también han sido inherentes al racionalismo, a la democracia y a la modernidad. Esta actitud es claramente detectable en casi todas las corrientes adscritas al postmodernismo - muy difundido en tierras del Nuevo Mundo -, y ha sido prefigurada por Walter Benjamin ${ }^{35}$ y posteriormente por algunos integrantes de la Escuela de Frankfurt. Como se sabe, al elaborar una crítica global del capitalismo y liberalismo, tanto la primera generación de la Escuela de Frankfurt como muchos

33 Cf. la brillante obra de Otfried Höffe, Moral als Preis der Moderne. Ein Versuch über Wissenschaft, Technik und Umwelt (La moral como precio de la modernidad. Un ensayo sobre ciencia, técnica y medio ambiente), Frankfurt: Suhrkamp 1993, pp. 113-114.- El autor se basa en las observaciones de Alexander von Humboldt acerca del trabajo humano sistemático en el Nuevo Mundo y sus consecuencias nefastas sobre la conservación del medio ambiente.

34 Es muy interesante el intento de hacer justicia a la obra precoz del escritor boliviano Man Césped (1874-1932), el primer defensor del medio ambiente y de prácticas conservacionistas en América Latina. Cf. Eduardo Gudynas, Ecología, economía y ética del desarrollo sostenible, La Paz: ICIB-ANCB / CLAES 2003, pp. 203-204.

35 Susan Buck-Morss, Orígenes de la dialéctica negativa. Theodor W. Adorno, Walter Benjamin y el Instituto de Frankfurt, México: Siglo XXI 1981; David Scafe, Walter Benjamin and the School of Frankfurt. String of Pearls, Los Angeles: UCLA 1999. 
intelectuales latinoamericanos de la izquierda radicalizada se han concentrado en aspectos muy generales y en una exégesis omnicomprensiva de la razón instrumental, que se inclina necesariamente a una concepción filosófico-literaria y hasta emotiva del fenómeno censurado, dejando de lado los detalles engorrosos de la realidad empírica. Esta interpretación estético-histórica, de claras reminiscencias románticas, enfatiza el camino de la razón instrumental hacia un ámbito inescapable de alienación ubicua y explotación despiadada y descuida paralelamente la esfera de la praxis política cotidiana, los progresos institucionales y los procesos de formación de voluntades políticas democráticas ${ }^{36}$. En este legado de origen romántico no puede haber lugar para intentos de reforma moderada y gradual; la consecuencia práctica puede ser descrita como la trivialización de la política propiamente dicha. Al mismo tiempo, este ímpetu revolucionario, dentro de la mejor tradición romántica, se preocupa casi exclusivamente por los grandes ideales heroicos - la revolución auténtica, la construcción del Hombre Nuevo, la solidaridad internacional - y le son indiferentes los pormenores desagradables de la vida cotidiana, la existencia de regulaciones burocráticas irracionales y la carencia de libertades efectivas. En este contexto no es superfluo mencionar las dificultades que se dan en países latinoamericanos para respetar aspectos calificados como meramente formales y para manejar fenómenos de logística compleja, que requieren perseverancia y conocimientos específicos.

\section{La ensayística latinoamericana como respuesta a la falta de reconocimiento}

Desde la primera mitad del siglo XIX se puede constatar en el Nuevo Mundo una rica tendencia intelectual consagrada a esbozar concepciones referidas a las preguntas por el destino y la vocación de sus sociedades. Aparte de la discusión primordial en torno a la libertad política y la prosperidad económica, otros temas más complejos ganaron paulatinamente en importancia, como la identidad nacional, la relación con las grandes potencias, la actitud adecuada frente al nuevo orden basado en la ciencia y la tecnología y la configuración de un futuro justo para sus pueblos. Estos temas recurrentes de la ensayística latinoamericana han estado concentrados, como es lo usual, en la esfera de la teoría y la retórica, pero hoy se puede aseverar que los grandes autores latinoamericanos contribuyeron desde un comienzo y eficazmente a percibir la complejidad de las cuestiones debatidas y a obtener una notable pluralidad de puntos de vista y programas de acción ${ }^{37}$. La continuidad de este debate y la pluralidad de sus planteamientos - y de

\footnotetext{
36 Helmut Dubiel, op. cit. (nota 26), pp. 92-93.

37 Cf. entre otros: Martin S. Stabb, América Latina en busca de una identidad. Modelos de ensayo ideológico hispanoamericano 1890-1960, Caracas: Monte Ávila 1969; Richard M. Morse, El espejo de Próspero. Un estudio de la dialéctica del Nuevo Mundo, México: Siglo XXI 1982; Leopoldo Zea, Filosofía de la historia americana, México: FCE 1978; José Joaquín Brunner, Los debates sobre la modernidad y el futuro de América Latina, en: Gonzalo Martner (comp.), Diseños para el cambio. Modelos socio-culturales, Caracas: Nueva Sociedad / UNITAR 1987, pp. 110-115.
} 
sus dudas - constituyen probablemente uno de los mejores legados culturales del Nuevo Mundo al saber universal.

La independencia de los estados latinoamericanos puede ser concebida como la intención expresa de los libertadores (y de los grupos dirigentes de la época) de dotar a estas tierras de un orden moderno, inspirado por los valores de la llustración y del racionalismo. Los autores latinoamericanos se percataron muy pronto de que las normativas ilustradas, a pesar de su calidad y prestigio, tenían una vigencia muy relativa en las sociedades europeas y en los países del Nuevo Mundo. Desde muy temprano la ensayística latinoamericana prestó atención a los vínculos tan intrincados que existen entre libertad política y justicia social, entre progreso económico y educación pública, entre consolidación nacional y unificación regional, y dio a conocer, mediante la variedad de sus programas, que no había una solución unitaria y simple para la multiplicidad de los desafíos históricos que enfrentaban las jóvenes naciones. Pese a la difusión de las concepciones liberales y a la autoridad de que gozaba el pensamiento racionalista, desde un comienzo los ensayistas llevaron a cabo una notable crítica del orden social reinante en Europa y de la ideología racionalista que lo acompaña, aunque, por supuesto, sin realizar un análisis detallado y empírico de aquello que posteriormente se conocerá como capitalismo. Esta crítica se concentra en aspectos culturales y religiosos, y exhibe una cierta similitud con el romanticismo del Viejo Mundo. Por otra parte hay que considerar una vigorosa opinión - de antigua data - que afirma que ni la Revolución Francesa ni el liberalismo británico tuvieron influencia sobre las corrientes que animaron la independencia de los países latinoamericanos, sino antiguas tradiciones culturales, como la religiosidad popular, el viejo autonomismo regional español y las ideas protodemocráticas derivadas del pensamiento municipalista de Castilla ${ }^{38}$.

Desde la primera mitad del siglo XIX la praxis política efectiva de los países latinoamericanos ha estado bastante alejada de los ideales racionalistas y liberales. Precisamente la consciencia de esta problemática, ardua, compleja y dolorosa, es la que ha motivado el nacimiento de las diversas líneas de la ensayística latinoamericana. La tensión entre la esfera del pensamiento y los programas, por un lado, y la vida prosaica del mundo cotidiano, por otro, ha originado en todos los modelos civilizatorios las reflexiones más fructíferas y profundas acerca de las dificultades de la convivencia razonable en el seno de las sociedades humanas y en torno a la función relativamente modesta de los esfuerzos teóricos. No hay duda, empero, de que los estados latinoamericanos - como pocos a escala mundial - han nacido con la intención expresa, típica de una modernidad precoz, de orientar sus actuaciones según los postulados de la llustración y el racionalismo, es decir de acuerdo a las aspiraciones más elevadas de su época. Y no hay que olvidar que simultáneamente estas corrientes de pensamiento creyeron que en el

38 Cf. la recapitulación crítica de esta porción de la historia de las ideas en la hoy olvidada obra de Enrique de Gandía, Historia de América, en: H. G. Wells, Esquema de la historia universal, Buenos Aires: Anaconda 1948, t. II, pp. 435-843, especialmente pp. 584-611. 
Nuevo Mundo se podría edificar una opción civilizatoria genuinamente propia y ejemplar en un periodo histórico signado por la injusticia y la irracionalidad ${ }^{39}$.

No se puede, obviamente, subsumir el variado y valioso tejido de la ensayística latinoamericana bajo un denominador único y simplificador, ya que la naturaleza misma del ensayo en cuanto género literario es plural, polémica y contradictoria, explorativa e hipotética. Se puede detectar, sin embargo, la recurrencia de algunos temas comunes a lo largo del tiempo y en la mayoría de los países: el anhelo de constituir una identidad social propia $^{40}$, la recuperación provechosa de los legados culturales del pasado, la confrontación permanente con la civilización metropolitana del Norte, la adopción selectiva de inventos, pautas de comportamiento e instituciones provenientes de culturas externas y el percatarse de la relevancia de la ciencia y la tecnología para la configuración exitosa de la vida contemporánea, considerando que el desarrollo de ambas no ha sido justamente el fuerte de la evolución social latinoamericana.

Otro tema común es la búsqueda de reconocimiento en el plano de la comunidad internacional de países soberanos. En este punto se da hasta hoy una unanimidad de pareceres entre todas las corrientes de la ensayística latinoamericana. Desde un comienzo el anhelo de ser reconocidos como iguales por los otros estados soberanos en el concierto de las naciones ha sido de una importancia tal, que exonera a este popular anhelo de toda fundamentación intelectual. La persistencia y la intensidad de esta aspiración son comprensibles porque esa comunidad internacional se ha empeñado hasta el tiempo presente en tratar a los estados latinoamericanos como países de segunda categoría y, con algunas excepciones, a sus representantes intelectuales como figuras de escasa significación. La proclamada igualdad de naciones y personas no pasa de ser - en numerosos casos - un buen deseo, un postulado teórico de poca repercusión en el campo prosaico de la realidad y, por lo tanto, no debería ser tomado al pie de la letra por los pensadores y políticos latinoamericanos. Pero como el ser humano habitualmente no aprende de las experiencias ajenas, los estratos dirigentes del Nuevo Mundo han creído en el valor normativo y hasta supremo de esos postulados verbales y no siempre han considerado adecuadamente la distancia proverbial entre teoría y praxis en todos los tiempos y bajo todos los regímenes políticos. Por otra parte, hay que consignar el hecho repetitivo de que el cosmopolitismo liberal, que también presupone la igualdad de pueblos y personas, es a menudo un principio vacío. Con alguna seguridad se puede aseverar que no logra concitar emociones sociales relevantes. Y para ser reconocido por otros en

\footnotetext{
39 Testimonios de esa tendencia en: Miguel Jorrín / John D. Martz (comps.), Latin-American Political Thought and Ideology, Chapel Hill: North Carolina U. P. 1970, passim.

40 Manfred Mols, Bemerkungen zur Identität Lateinamerikas (Observaciones sobre la identidad de América Latina), en: Michael Riekenberg et al. (comps.), Kultur-Diskurs: Kontinuität und Wandel der Diskussion um Identitäten in Lateinamerika im 19. und 20. Jahrhundert (Discurso de la cultura: continuidad y cambio de la discusión sobre identidades en América Latina en los siglos XIX y XX), Stuttgart: Akademischer Verlag Heinz 2011, pp. 453-466.
} 
igualdad de condiciones o, por lo menos, de posibilidades futuras, se requiere de empatía, es decir de un mínimo de emoción. El orden moderno, tanto en su variante liberal como en otras de corte autoritario, no ha sido precisamente proclive a generar este tipo de sentimientos.

En esta constelación es comprensible que hayan surgido en América Latina varias respuestas de carácter a veces romántico con respecto a la modernidad y a la democracia liberal, y que estas respuestas se hayan mezclado inextricablemente con la problemática del reconocimiento a nivel internacional. La pluralidad de críticas y proyectos alternativos en el seno de la ensayística ha contribuido, por lo tanto, a buscar y encontrar nuevos horizontes teórico-heurísticos y a resaltar el valor de los elementos culturales y simbólicos con respecto a la evolución como totalidad - como es el caso del reconocimiento a nivel global -, lo que nos muestra que la ensayística desde un principio ha sostenido adecuadamente que los aspectos socio-económicos no son los únicos factores dignos de ser tenidos en cuenta.

\section{La ensayística antiliberal y la crítica romántica de la modernidad capitalista}

La línea más conocida e influyente de la ensayística latinoamericana es la que puede ser caracterizada como antiliberal ${ }^{41}$. Este calificativo es inexacto e injusto para aprehender tendencias bastante disímiles en el pensamiento del Nuevo Mundo, y por ello es utilizado aquí provisionalmente como el mal menor a falta de una denominación más adecuada. Esta corriente de la ensayística latinoamericana puede ser tildada de conservadora, porque reproduce los elementos más usuales de la tradición católica y del romanticismo: el repudio del cosmopolitismo liberal, el rechazo del pluralismo ideológico y cultural, la indiferencia frente al Estado de derecho y a los valores democráticos pluralistas y la crítica, a veces muy acertada, del libre comercio y de la economía basada en la propiedad privada de los medios de producción. Numerosos autores de esta tendencia exhiben una propensión nacionalista y colectivista, un claro rechazo de posiciones antilaicas, una significativa "comprensión" de las tradiciones caudillistas y populistas en la esfera política y una inclinación provinciana y nacionalista, favorable a los usos y costumbres que vienen de muy atrás y de las "entrañas" de la tierra. Y todo esto puede combinarse relativamente bien con una propuesta modernizadora circunscrita a la esfera técnico-económica ${ }^{42}$.

En la actualidad y bajo la fuerte influencia de teorías postmodernistas, estos ensayistas

41 Loris Zanatta, El populismo, entre religión y política. Sobre las raíces históricas del antiliberalismo en América Latina, en: ESTUDIOS INTERDISCIPLINARIOS DE AMÉRICA LATINA Y EL CARIBE (Tel Aviv), vol. 19, No 2, julio-diciembre de 2008, pp. 29-44.

42 Carmen L. Bohórquez, Caudillismo y modernidad en Laureano Vallenilla Lanz, en: Hugo Cancino (comp.), Los intelectuales latinoamericanos entre la modernidad y la tradición, siglos XIX y XX, Madrid I Frankfurt: Iberoamericana / Vervuert 2004, pp. 35-49. 
han adoptado, por supuesto, un ropaje intelectual a la moda del día, como son los cultural studies y afines (estudios subalternos y postcoloniales) de la academia norteamericana. En este contexto se puede percibir un renacimiento de posiciones teluristas, comunitaristas, indigenistas e indianistas, es decir una nueva apreciación positiva de todos aquellos legados civilizatorios que aparentemente están opuestos a la tradición occidental capitalista, individualista y universalista. Muchos de estos ensayistas se adhieren al autoritarismo político y favorecen élites fuertes que "saben" guiar moralmente y hacer progresar a la nación respectiva. En una posición muy similar a la antigua Teoría de la Dependencia, son partidarios de la industrialización masiva bajo clases dirigentes nacionalistas (como ellos creen, por ejemplo, que han sido las élites modernizadoras japonesas $)^{43}$.

En el ámbito andino esta corriente favorece una revigorización de valores autóctonos, indigenistas y telúricos, llegando a rechazar las formas usuales - e ineludibles - de convivencia y cultura contemporáneas como el mestizaje ${ }^{44}$. En esta constelación es indispensable mencionar en passant que la historia universal puede ser interpretada, por lo menos de manera parcial, como un proceso con innumerables fenómenos de mestizaje y aculturación. La historia significa también contacto con lo foráneo y, a veces, comprensión de lo extraño. El mestizaje puede ser obviamente traumático, pero también enriquecedor $^{45}$. Hasta se podría afirmar que las sociedades más exitosas han sido aquellas que han experimentado un número relativamente elevado de procesos de aculturación y que los individuos más aptos son los que tienen una multiplicidad de roles. El tratar de volver a una identidad previa a toda transculturación - como la precolombina, pues varios sectores políticos lo propugnan en el área andina - es, por lo tanto, un esfuerzo vano, anacrónico y hasta irracional: se puede pasar rápidamente de las reivindicaciones anti-imperialistas a las obsesiones nacionalistas y a los ensayos de limpieza étnica por la fuerza de las armas.

Los factores centrales de esta concepción fueron anticipados por el mexicano Lucas Alamán (1792-1853), quien puede ser calificado como el primer ensayista latinoamericano. Este aristócrata católico tuvo una considerable influencia sobre la vida política y cultural de su país en el siglo XIX. Era un gran admirador de la evolución industrial británica y simultáneamente un partidario de la cultura política y religiosa del hispanismo tradicional ${ }^{46}$;

\footnotetext{
43 Cf. entre otros estudios críticos: Robert Packenham, The Dependency Movement: Scholarship and Politics in Development Studies, Cambridge: Harvard U. P. 1992.

44 Cf. Otto Morales Benítez, La identidad: el mestizaje indoamericano y la universalidad, en: Michael Riekenberg et al. (comps.), op. cit. (nota 40), pp. 301-315; para el caso boliviano cf. Javier Sanjinés C., El espejismo del mestizaje, La Paz: IFEA / PIEB 2005, passim.

${ }^{45}$ Cf. Roger Bastide, El prójimo y el extraño. El encuentro de las civilizaciones, Buenos Aires: Amorrortu 1973.

46 Cf. Salvador Méndez Reyes, El hispanismo de Lucas Alamán (1792-1853), Toluca: UAEM 1996; Guillermo Zermeño, La historia, una ciencia de Estado. Notas sobre la función social del historiador en
} 
fue un propulsor enérgico de lo que ahora llamaríamos proyectos ambiciosos de desarrollo económico y, al mismo tiempo, un defensor decidido de la mano fuerte en el campo político-institucional. No tenía ninguna simpatía por la libertad de discusión y por los cuerpos deliberativos; detestaba toda manifestación de heterogeneidad estructural y percibía la solución de los problemas mexicanos en una sólida unión entre gobierno, ejército y clero $^{47}$. Salvando las distancias y actualizando los conceptos, Alamán parece un defensor del populismo autoritario a comienzos del siglo XXI. Por ejemplo: la elevada concepción que tenía Alamán del catolicismo de su época es muy diferente a la actual valoración positiva de la religiosidad popular. Pero en un punto central se da una coincidencia sintomática. Alamán, como numerosos pensadores de tendencia conservadora, creía en la función político-instrumental de la religiosidad popular que consiste en domeñar al pueblo y canalizar sus ímpetus mesiánico-utópicos hacia metas inofensivas y bajo la dirección de las élites convencionales. Las posiciones barrocorománticas de los intelectuales izquierdistas de la actualidad ven en la religiosidad popular un modelo contemporáneo de solidaridad ${ }^{48}$ masiva de los explotados y una expresión de la esperanza revolucionaria bajo ropaje tradicional. En ambos casos el llamado ethos barroco fomenta el colectivismo de las masas, el acatamiento de caudillos populistas y el rechazo del "cosmopolitismo liberal" 49 .

A primera vista hay una gran distancia entre esta doctrina esencialmente conservadora y la ensayística posterior de corte nacionalista y socialista, pero analizando detenidamente la cuestión se advierte claramente las similitudes entre ambas posiciones. Por ello es conveniente dar un vistazo a la obra del argentino Manuel Ugarte (1875-1951), quien puede ser considerado como uno de los precursores más importantes de corrientes izquierdistas en el Nuevo Mundo y cuya obra experimenta ahora un renacimiento sintomático. Ugarte tuvo una notable influencia sobre la conformación de lo que podemos llamar la consciencia intelectual latinoamericana en torno a la identidad y el futuro del continente. Estuvo influido, como gran parte de su generación, por el uruguayo José Enrique Rodó (1871-1917) y su propuesta del arielismo ${ }^{50}$, pero supo moldear una concepción propia con elementos nacionalistas y con un claro giro político izquierdista. Su idea de la "Patria Grande"51 ha tenido desde entonces una enorme repercusión, pues

México en el siglo XIX, en: Hugo Cancino (comp.), op. cit. (nota 42), pp. 19-33, especialmente pp. 20-23.

47 Lucas Alamán, Semblanzas e ideario, México: UNAM 1963, pp. 164-166.

48 Sobre la temática de la solidaridad cf. el interesante compendio de Kurt Bayertz (comp.), Solidarität. Begriff und Problem (Solidaridad. Concepto y problema), Frankfurt: Suhrkamp 1998, especialmente: Nicholas Capaldi, Was stimmt nicht mit der Solitarität? (¿Qué cosa no funciona con la solidaridad?), en: ibid., pp. 86110.

49 Para una versión diferente en torno al ethos barroco cf. Stefan Gandler, Marxismo crítico en México: Adolfo Sánchez Vázquez y Bolívar Echeverría, México: FCE / UNAM 2007, pp. 391, 417-424.

50 José Enrique Rodó, Ariel [1900], México: Porrúa 1968, pp. 15-16, 26-37. Cf. Leopoldo Zea, Discurso desde la marginación y la barbarie, Barcelona: Anthropos 1988, p. 128.

51 Manuel Ugarte, La patria grande, Madrid: Editorial Internacional 1922, passim.- Desde la izquierda nacionalista y peronista cf. la amplia reivindicación de Norberto Galasso, Manuel Ugarte, Buenos Aires: 
combina la herencia antiliberal de vieja data, la malquerencia y el rencor con respecto a los Estados Unidos, la retórica general anti-imperialista y el redescubrimiento de lo positivo inmerso en las tradiciones propias. La compleja relación asimétrica con los Estados Unidos ocupa desde entonces un lugar predominante en la ensayística latinoamericana, que no lo poseía en la obra de los primeros autores como Lucas Alamán o Domingo Faustino Sarmiento. Esa asimetría está relacionada directamente con la falta de reconocimiento de los países latinoamericanos a nivel internacional. No hay duda de que Ugarte tuvo el mérito de estudiar las causas profundas de esa carencia fundamental, temática que evidentemente no fue incluida en los análisis de pensadores liberales como Sarmiento. La relevancia de Ugarte y de sus numerosos seguidores reside en el hecho de que ellos han percibido claramente esa asimetría, dando así los primeros e indispensables pasos para superarla.

La doctrina de Ugarte constituye, con las salvedades del caso, el programa intelectual imperante hasta hoy en los llamados círculos, movimientos y partidos "progresistas". Ugarte mismo tuvo simpatías por el peronismo - aunque se desilusionó prontamente -, pero no se preocupó por los aspectos autoritarios, paternalistas, colectivistas y antipluralistas que también distinguieron al peronismo y los regímenes nacionalistas de su tiempo. Siguiendo a Rodó, Ugarte rechazó, por otra parte, el utilitarismo vulgar y el materialismo grosero de la sociedad norteamericana, suponiendo que las naciones de origen latino representaban una alternativa ética y estéticamente más aceptable. Este programa, muy difundido hasta hoy, denota, sin embargo, un factor altamente problemático, que es la "reconciliación con el pasado hispánico"52, la cual, en teoría y praxis, ha conllevado a ver en una luz positiva el legado político-institucional de esa herencia autoritaria y antiliberal.

La línea doctrinaria de Ugarte tiene en común con el romanticismo un carácter poco claro conceptualmente, pero muy proclive a sentimientos de gran arrastre popular. A ambas corrientes les es propia una marcada propensión a un estilo retumbante y a una fraseología altisonante y belicosa, que encubren apenas la carencia de ideas claras sobre el futuro y acerca de las políticas públicas concretas que se pretende implementar. Esta incongruencia entre una retórica frondosa y una orfandad de planes realistas y específicos se advirtió claramente con ocasión de la guerra hispano-norteamericana de 1898. El debate intelectual y periodístico de entonces reavivó dos motivos de gran peso que han perdurado hasta hoy en el imaginario colectivo de extensos sectores poblacionales, motivos que - en diferentes dosis - prevalecen también en la producción académica, sobre todo en el área andina, México y América Central: (a) la crítica del imperialismo norteamericano y (b) la búsqueda de una identidad nacional propia e inconfundible, precisamente cuando las incursiones de la modernidad occidental amenazan con barrer

EUDEBA 1973 (dos volúmenes).

52 Martín Bergel, El anti-antinorteamericanismo en América Latina (1898-1930), en: NUEVA SOCIEDAD (Buenos Aires), № 236, noviembre-diciembre de 2011, pp. 152-167, aquí p. 157. 
las diferencias identificatorias de los pueblos. Esta constelación es altamente favorable a ver los valores de orientación y las pautas recurrentes de comportamiento de las culturas precolombinas y de la época colonial española bajo una perspectiva parcializada que pasa por alto los aspectos autoritarios, antipluralistas y paternalistas de aquellos modelos civilizatorios. La retórica anti-imperialista ha cumplido "un inapreciable papel en la construcción de consensos y legitimidades" en la "cultura política nacional-popular, de consabido e inveterado arraigo en América Latina"53.

En el último medio siglo estas ideas se han actualizado y diferenciado mediante los aportes de las ciencias sociales y económicas, ante todo bajo la influencia de las diversas escuelas sucesorias del marxismo. Ha perdido influencia la concepción romántica de vincular la pluma y el fusil ${ }^{54}$, es decir la celebración entusiasta del nexo entre teoría progresista y praxis revolucionaria en la misma persona, como se creyó ver encarnado este vínculo en los luchadores de la Revolución Cubana. Paulatinamente ganó en relevancia la llamada "economización de agravios"55: la distancia creciente entre el desarrollo de los llamados centros metropolitanos (Europa Occidental y Estados Unidos) y el subdesarrollo de las naciones latinoamericanas se debería principalmente a la acción perniciosa del imperialismo promovido por los países del Norte. La ensayística del Nuevo Mundo influida por los estudios económicos tiende a la exculpación de los factores endógenos por el atraso relativo del Tercer Mundo y a la percepción de las causas del subdesarrollo en la política imperialista de penetración y dominación ejercida por los centros metropolitanos.

Esta economización de la historiografía conlleva curiosos efectos en el campo políticoinstitucional, que se derivan claramente de la tradición antiliberal latinoamericana. Los dos publicistas más conocidos de esta corriente, Jorge Abelardo Ramos y Eduardo Galeano, reivindican a regímenes dictatoriales, que aparentemente habrían defendido la "dignidad nacional" contra las intromisiones imperialistas. Esos gobiernos habrían tratado, al mismo tiempo, de inducir una estrategia "propia" de modernización basada en una industrialización "original", de acuerdo con las necesidades "reales" de las sociedades latinoamericanas. Es particularmente interesante y expresiva la apología que ambos autores han realizado de las dictaduras del doctor José Gaspar Rodríguez de Francia en Paraguay y de Juan Manuel de Rosas en Argentina, pues ambos caudillos edificaron en la primera mitad del siglo XIX regímenes particularmente despóticos, cuyos logros

\footnotetext{
53 Ibid., p. 154. Cf. también Oscar Terán, Nuestros años sesentas. La formación de la nueva izquierda intelectual argentina, Buenos Aires: El Cielo por Asalto 1993.

54 Cf. el estudio de Claudia Gilman, Entre la pluma y el fusil: debates y dilemas del escritor revolucionario en América Latina, Buenos Aires: Siglo XXI 2003.

55 Aldo Marchesi, Imaginación política del anti-imperialismo: intelectuales y política en el Cono Sur a fines de los sesenta, en: ESTUDIOS INTERDISCIPLINARIOS DE AMÉRICA LATINA Y EL CARIBE, vol. 17, Nº 1, enero-junio de 2006, pp. 135-160.
} 
económicos - si es que realmente existieron - fueron modestísimos ${ }^{56}$. Ambos autores atribuyen a estos sistemas profundamente autoritarios una serie de virtudes ético-políticas de amplio alcance popular y los enaltecen a la categoría de modelos precursores de la Revolución Cubana a causa de su presunta autonomía con respecto a los centros metropolitanos. Al estudiar el régimen del doctor Francia en el Paraguay, Galeano hace el abierto encomio del "Estado omnipotente, paternalista", que habría tomado a su cargo (y de modo muy original) "la tarea de organizar la nación y orientar sus recursos y su destino"57. Galeano concede que durante este gobierno ocurrieron vulneraciones de los derechos humanos y que no existían "las libertades políticas y el derecho de oposición", pero aclara inmediatamente que sólo aquellos que acariciaban nostalgia por "los privilegios perdidos" podían sentir como negativa "la falta de democracia"58.

Aquí es importante señalar un aspecto repetitivo y fundamental de la ensayística antiliberal. Un sistema político, considerado como altamente positivo y hasta paradigmático por su desempeño económico-técnico - o por la pretensión propagandística de serlo -, es eximido de toda crítica referida al campo político-institucional: el presunto éxito en la industrialización o en la construcción de la autonomía económica con respecto a los centros metropolitanos hace aparecer como secundarias las preocupaciones por las libertades públicas y los derechos humanos. Esta trivialización de los elementos represivos en la esfera política es común a casi todas las tendencias nacionalistas y socialistas del pensamiento latinoamericano y contribuye a dar un nuevo lustre, esta vez progresista, al viejo principio de que el fin justifica los medios ${ }^{59}$. Esta concepción es más frecuente de lo que se cree. El mexicano Leopoldo Zea (1912-2004), el gran pensador de la autenticidad latinoamericana, analizó las complejas interrelaciones entre los centros metropolitanos y las periferias mundiales ("diálogos entre discursos"), y llegó a la conclusión de que una cierta apropiación de los modelos evolutivos de los centros sería inevitable; Zea abogó entonces por una adopción creativa y original de aquellos paradigmas de desarrollo. Pero en el despliegue de su argumentación, realizada en base a datos muy escasos de la realidad histórica, Zea consideró la obra modernizadora del zar Pedro I el Grande (1689-1725) como modélica porque instauró en Rusia un proceso acelerado de occidentalización e industrialización sin mayor consideración de los costes humanos del magno experimento social ${ }^{60}$. Como se sabe, la modernización parcial emprendida por este monarca contribuyó eficazmente a consolidar el despotismo habitual

56 Jorge Abelardo Ramos, Introducción a la América criolla, Buenos Aires 1985, cap. III; Eduardo Galeano, Las venas abiertas de América Latina, Buenos Aires: Siglo XXI 1975, pp. 283-302.- Para una crítica temprana de estos enfoques cf. Carlos Rangel, El tercermundismo, Caracas: Monte Ávila 1982, pp. 150-153.

57 Galeano, op. cit. (nota 56), p. 294.

58 Ibid., pp. 294-295.

59 Cf. Mario Benedetti, El desexilio y otras conjeturas, Madrid: El País 1984, p. 159: Habría que escribir una historia intencionadamente no objetiva de América Latina, que resalte las causas obviamente exógenas del subdesarrollo, pues el conocer y considerar los aspectos negativos de la cultura política sería caer en la "trampa de la objetividad".

60 Leopoldo Zea, Discurso..., op. cit. (nota 50), pp. 106-108. 
de aquella sociedad semi-asiática, empezando por el centralismo y terminando en el rechazo del Estado de derecho ${ }^{61}$. Y precisamente esta constelación - la meta de la modernización técnico-económica justifica plenamente la represión en los terrenos político, institucional y cultural - es lo que atrae a Leopoldo Zea y a muchos intelectuales latinoamericanos como una solución enérgica y adecuada de un problema que se arrastra desde la independencia a comienzos del siglo XIX. Se supone ingenuamente que la envergadura y la intensidad de las reformas petrínicas en la Santa Rusia (u otras similares, como la Revolución Cubana $^{62}$ ) ayudarán a fortalecer la dignidad nacional, es decir a ganar el reconocimiento anhelado en el concierto de naciones, por un lado, y a revigorizar una cultura propia, no contaminada por el capitalismo uniformizador, por otro.

Para estas corrientes de la ensayística latinoamericana, marcadas por un evidente colectivismo, el Estado de derecho y el pluralismo ideológico resultan fenómenos de relevancia muy accesoria. Lo importante para ellas es en cambio el derecho del Estado de disponer sobre todos los recursos materiales y humanos en pro de las grandes metas de evolución histórica, lo que representa, en el fondo, la expectativa convencional del pensamiento tecnocrático: la preservación de la rutinaria cultura política del autoritarismo y una visión meramente instrumental de la democracia. En toda América Latina existe hasta hoy en el imaginario popular la idea de que ambos factores contribuyen de modo enérgico al desarrollo acelerado ${ }^{63}$.

La dilatada influencia de los ensayistas latinoamericanos izquierdistas y nacionalistas sobre la opinión pública estriba en que ellos han sabido, mediante notables intuiciones, abordar algunos temas insoslayables para la conformación de la identidad colectiva y la consciencia intelectual de su época y proponer una síntesis entre el legado autoritario de vieja data y los logros técnico-económicos de la civilización industrial contemporánea. Esta simbiosis se percibe claramente en la obra del cubano Roberto Fernández Retamar (*1930), quien ha tratado de establecer una tradición propia y auténtica del pensamiento latinoamericano, definida ex negativo (ya no somos occidentales) y basada en los elementos antiliberales de la herencia hispano-católica y simultáneamente en el desempeño técnico-económico del llamado desarrollo acelerado. La teoría de Fernández Retamar intenta establecer un vínculo lógico y duradero entre la cultura política de la España colonial y el socialismo cubano de la actualidad, iluminado por la obra de José Martí, Fidel Castro y Ernesto Che Guevara, a quienes el autor atribuye considerables

61 Para una visión crítica de esta temática cf. Umberto Melotti, Marx y el Tercer Mundo, Buenos Aires: Amorrortu 1974, pp. 125-130; Richard Pipes, Russland vor der Revolution. Staat und Gesellschaft im Zarenreich (Rusia antes de la revolución. Estado y sociedad bajo el imperio de los zares), Munich: dtv 1984, passim.

62 Darcy Ribeiro, A patria grande, Río de Janeiro: Guanabara 1986, pp. 104-105.

63 Para el caso boliviano y con referencia al teórico más conocido de su izquierda nacionalista, cf. Fernando Molina, René Zavaleta. La etapa nacionalista, La Paz: Gente Común 2011, p. 75. 
méritos filosóficos ${ }^{64}$. El autoritarismo del pasado aparece entonces como un conjunto de valores de orientación y pautas recurrentes de comportamiento que sería apropiado a la idiosincrasia popular de tiempos actuales; el antiliberalismo de la Revolución Cubana y su desdén por el Estado de derecho y el pluralismo ideológico se amoldarían perfectamente a las tradiciones colectivas de profunda raigambre histórica. Fernández Retamar relativiza los aspectos negativos de la colonia española mediante el cómodo argumento de que los otros modelos de colonización fueron igualmente malos o peores. La Leyenda Negra aparece como un mero libelo anti-español ${ }^{65}$.

Finalmente hay que señalar que la ensayística antiliberal ha realizado a lo largo del siglo XX considerables esfuerzos para diferenciar el llamado nacionalismo progresista del nacionalismo reaccionario ${ }^{66}$. Esto es esencial para una corriente de pensamiento que trata de rescatar elementos primordiales de tradiciones profundamente arraigadas en el pasado latinoamericano. Estas herencias culturales tienen su origen en la era precolombina y en la época colonial española y se distinguen, como se ha mencionado a lo largo de este texto, por el anticosmopolitismo, el antiliberalismo y, sobre todo, por una visión edulcorada de regímenes populistas y caudillistas de los siglos XIX y XX, cuyo único mérito radica en esfuerzos modernizadores de corte autoritario $y$ en manifestaciones verbales antinorteamericanas, de escaso efecto práctico, pero de gran visibilidad propagandística. Ahora se trata de demostrar que esos sistemas socio-políticos han sido, en el fondo, progresistas, diferentes de los regímenes reaccionarios, es decir de aquellos favorables a los intereses de los Estados Unidos y del imperialismo británico.

Estas líneas de pensamiento estuvieron inspiradas por el revisionismo histórico en la Argentina a partir de aproximadamente 1930, que resultó ser fervientemente antiliberal y prohispanista, a menudo con elementos doctrinales propicios al catolicismo integrista. (En la actualidad esta última tendencia ha sido reemplazada por un fuerte impulso favorable al ethos barroco católico.) Ha sido ante todo una concepción difundida por pensadores proclives al peronismo y de procedencia conservadora, como el gran historiador y novelista Manuel Gálvez (1882-1962). La idea central es muy simple: el liberalismo habría distorsionado perversamente la historia argentina, la profunda, la auténtica, la nacional, es decir, la que no fue influida o contaminada por el universalismo y el racionalismo europeos $^{67}$. El genuino deber intelectual y público-político sería retornar a esa base sana

64 Roberto Fernández Retamar, Nuestra América y Occidente, en: CASA DE LAS AMÉRICAS (La Habana), vol. 17 (1976), № 98, pp. 36-57; Fernández Retamar, Para el perfil definitivo del hombre, La Habana: Letras Cubanas 1976, pp. 285-292, 520-538.

65 Roberto Fernández Retamar, Contra la Leyenda Negra, en: CASA DE LAS AMÉRICAS, vol. 17 (1976), $\mathrm{N}^{\circ}$ 99, pp. 28-41.

66 Cf. uno de los primeros y más importantes intentos: Juan José Hernández Arregui, La formación de la conciencia nacional 1930-1960, Buenos Aires: Hachea 1960.

67 Cf. los estudios críticos: Maristella Svampa, El dilema argentino: civilización o barbarie. De Sarmiento al revisionismo peronista, Buenos Aires: El Cielo por Asalto 1994; Michael Goebel, Marxism and the Revision of Argentine History in the 1960s, en: ESTUDIOS INTERDISCIPLINARIOS DE AMÉRICA LATINA Y EL 
de una mentalidad realmente propia, sentida y aceptada como tal por el grueso de la población y por los intelectuales progresistas. Es fácil comprender la inmensa popularidad de esta concepción central, que mediante regímenes populistas conoce un notable renacimiento en las primeras décadas del siglo XXI.

\section{Dilemas centrales del pensamiento socio-político en América Latina}

La ensayística latinoamericana engloba muy diferentes corrientes ideológicas, lo que, como se ha dicho, constituye uno de sus aspectos más positivos y promisorios. Desde la primera mitad del siglo XIX las tendencias pro-occidentales han sido importantes, pues parecían encarnar el espíritu progresista de la época. Los pensadores adscritos a esta línea ideológica creían que la búsqueda de soluciones originales para el desarrollo del Nuevo Mundo era inútil, pues ya existía el paradigma evolutivo por excelencia: la civilización moderna, urbana, industrial, laica y moderadamente democrática, encarnada entonces por los países más adelantados de Europa Occidental (Francia y Gran Bretaña) y los Estados Unidos. Mediante la imitación de esos ejemplos se esperaba mejorar sustancialmente la importancia de los países latinoamericanos en el concierto de las naciones y alcanzar el reconocimiento internacional que el Nuevo Mundo merecía a escala planetaria.

Los dos primeros representantes de esta tendencia fueron los argentinos Juan Bautista Alberdi (1810-1884) y Domingo Faustino Sarmiento (1811-1888); su posición básica puede ser calificada como pro-europeísta y anti-indigenista. Alberdi sostenía que la inmigración europea era sinónimo de progreso y que la imitación del desarrollo británico, basado en la industria y el comercio, representaría "el gran medio de moralización"68 de los pueblos. Para Sarmiento los factores adversos al progreso eran los caudillos federales del interior argentino, agentes y propagadores de la fatalidad de la historia y de la herencia hispano-católica. El legado cultural asociado a España fue visto por Sarmiento como anticuado, bárbaro e imprevisible ${ }^{69}$.

Para los integrantes de esta corriente en el siglo XIX, la tarea civilizadora era partir pragmáticamente de la única realidad entonces detectable, que eran las repúblicas iberoamericanas en su conformación momentánea, pues tanto los modelos institucionales indígenas como la concepción de una Patria Grande, que abarque todos los países

\footnotetext{
CARIBE, vol. 17, № 1, enero-junio de 2006, pp. 161-184, especialmente p. 163.

68 Juan Bautista Alberdi, Bases y puntos de partida para la organización política de la República Argentina [1852], Buenos Aires: CEAL 1979, pp. 51-59.

69 Domingo Faustino Sarmiento, Facundo. Civilización y barbarie [1845], Madrid: Alianza 1970, pp. 17, 172-174.- Cf. una crítica desde la izquierda convencional: Roberto Fernández Retamar, Algunos usos de civilización y barbarie, en: REVISTA MEXICANA DE SOCIOLOGÍA (México), vol. LI, № 3, julio-septiembre de 1989, pp. 291-325.
} 
latinoamericanos, representarían ideas utópicas, alejadas de las posibilidades reales del momento y del paradigma evolutivo modernizador de Europa Occidental. Contra las corrientes nacionalistas e indigenistas, estos pensadores creían que no existía un núcleo identificatorio de la nación, definible en términos esencialistas, que mereciera ser rescatado. Alberdi y Sarmiento reconocían la enorme brecha existente entre la realidad cotidiana de aquella época y el paradigma occidental, y aseveraban que la obligación de todo gobierno era reducir esa distancia educando al pueblo en el espíritu democrático de las instituciones modernas e impulsando el mérito y el talento individuales como factores privilegiados del desarrollo social, propugnando asimismo el fortalecimiento de una cultura política liberal-cosmopolita y afianzando el imperio de la ley y la vigencia de los derechos humanos.

Es evidente que estas corrientes pro-occidentales han descuidado la compleja problemática étnico-cultural, policlasista y plurilingüe de muchas sociedades latinoamericanas. Han cultivado, al mismo tiempo, una cierta ingenuidad ${ }^{70}$ que reaparece en el máximo exponente actual del pensamiento liberal, Mario Vargas Llosa (*1936), al suponer que la educación de las masas en un espíritu liberal, democrático e individualista iba a la larga a igualar las periferias mundiales con los centros metropolitanos y a generar un debilitamiento de las propensiones populistas de las sociedades latinoamericanas. En la formulación de las metas normativas de evolución y en la configuración de los aspectos institucionales, los ensayistas liberales rechazaron conscientemente todo intento de originalidad y novedad y recomendaron para sus países la reproducción (eso sí: bien hecha) de aquellos sistemas de organización social y política que habían dado resultados más o menos razonables en las naciones del Norte.

En la actualidad la renovada vigencia del revisionismo histórico ha devaluado el peso y el alcance de las doctrinas liberales. Este fenómeno ha llevado paulatinamente, para citar un ejemplo elocuente, a que en la Argentina Sarmiento se convierta en un intelectual menor: ahora dilatados sectores sociales lo perciben como el admirador candoroso de la modernidad capitalista europea, el introductor de una forma subalterna de cultura capitalista y el presidente que hizo causa común con la oligarquía terrateniente ${ }^{71}$.

Como contraste a muchas aseveraciones de este texto, hay que mencionar la existencia de una corriente crítica en el seno de la ensayística latinoamericana. Esta tendencia comparte con los pensadores pro-occidentales una actitud distanciada con respecto al acervo cultural aborigen, a las tradiciones hispánico-católicas y a las prácticas nacionalistas y populistas. Esta línea se distingue, entre otras características, por una

70 Entre la abundante literatura sobre este autor cf. Pablo Rolando R. Cristoffanini, Mario Vargas Llosa y el nuevo discurso de las élites latinoamericanas, en: Hugo Cancino (comp.), op. cit. (nota 42), pp. 113-124.

71 Cf. por ejemplo: José Luis de Diego, ¿Quién de nosotros escribirá El Facundo? Intelectuales y escritores en Argentina (1970-1986), La Plata: Ediciones al Margen 2001; Silvia Sigal, Intelectuales y poder en Argentina: la década del sesenta, Buenos Aires: Siglo XXI 2002. 
oposición matizada con respecto a los paradigmas occidentales y metropolitanos de evolución histórica. El ya nombrado José Enrique Rodó hizo una importante contribución a esta concepción mediante su rechazo ético y estético de la civilización industrial y comercial encarnada por los Estados Unidos (el predominio del número sobre la calidad). El representante más ilustre de la ensayística crítica es seguramente Octavio Paz (19141998), quien ha combinado una visión escéptica en torno a la modernidad y sus paradigmas con un análisis luminoso de los legados culturales y de las mentalidades colectivas, especialmente la mexicana. Lo que se denomina de manera imprecisa el carácter nacional de un pueblo es, según Paz, una identidad colectiva plural, cambiante y equívoca, pero con algunos rasgos distintivos que la hacen aparecer también como un muro construido para defender la comunidad nacional de un mundo externo reputado como peligroso y falaz y, al mismo tiempo, como una máscara que expresa necesidades y anhelos populares, pero que asimismo puede impedir el despliegue de consciencias individuales disidentes ${ }^{72}$.

Paz llamó la atención acerca de tradiciones históricas que han sido positivas y promisorias en algunos campos (como las artes plásticas, la literatura y el logro de una solidaridad efectiva, no mediada burocráticamente), pero que han resultado autoritarias y antidemocráticas en el terreno político-institucional ${ }^{73}$. Paz criticó las estructuras altamente centralistas, jerárquicas y piramidales y la pervivencia de los caudillos en las civilizaciones precolombinas, en la era colonial ibérica y en el presente republicano; la enseñanza de la historia en las escuelas y la opinión pública alimentarían una visión edulcorada y embellecida - con claros elementos románticos - acerca de un pasado glorioso y exento de las alienaciones modernas. Precisamente esta perspectiva premeditadamente falsa de la historia evita un análisis crítico de la misma que pudiera tener consecuencias sociales y contribuye en cambio a perpetuar una mentalidad autoritaria. Uno de los mayores méritos de Octavio Paz consiste en haber realizado una crítica radical del poder político, señalando sobre todo el aspecto elitista del mismo. En lugar de basarse en una deliberación pública y razonable, la política en América Latina se distinguiría hasta hoy por ser un fenómeno de manipulación de consciencias, que tiene lugar en la oscuridad e imprecisión impuestas por dirigencias privilegiadas, lo que se puede observar claramente en movimientos populistas y partidos socialistas. La falta de una dimensión crítica sería, según Paz, uno de los mayores problemas de América Latina, pues esta región habría nacido con el espíritu de cruzada, la Contrarreforma, el Estado absolutista, el centralismo absorbente y la fusión entre lo religioso y lo político, es decir, de espaldas a la modernidad, a la llustración y al pensamiento liberal-democrático ${ }^{74}$.

72 Octavio Paz, El laberinto de la soledad, México: FCE 1950, passim.

73 Octavio Paz, Posdata, México: Siglo XXI 1976, pp. 132-133.- En esta línea cf. también los olvidados ensayos de Carlos Rangel, Del buen salvaje al buen revolucionario, Caracas: Monte Ávila 1977; Rangel, El tercermundismo, Caracas: Monte Ávila 1982; Rangel, Marx y los socialistas reales, Caracas: Monte Ávila 1988.

74 Octavio Paz, Tiempo nublado, Barcelona: Seix Barral 1983, pp. 144-152, 163-164; Octavio Paz, 
La obra de Octavio Paz es notable porque pone en cuestionamiento el carácter paradigmático y las pretendidas bondades de los centros metropolitanos. La originalidad teórica de este autor estriba en haber dirigido su impulso crítico a dudar de que el modelo civilizatorio del Norte industrializado - en todas sus variantes - deba ser imitado en el Tercer Mundo. Los ensayistas de la corriente anti-occidental han censurado los comportamientos de las potencias metropolitanas con respecto a América Latina (la "explotación imperialista"), pero nunca han propuesto metas normativas últimas (modernización, industrialización, Estado racionalmente organizado, alto nivel de vida y consumo, relación con la naturaleza) que sean sustancialmente diferentes a las ya alcanzadas en las potencias metropolitanas. Esto es particularmente evidente en aquellos pensadores de orientación socialista, para quienes el objetivo de la evolución histórica estaba preformado por lo alcanzado en la Unión Soviética o China. Octavio Paz dirigió los dardos de su análisis a la configuración política y cultural del antiguo bloque socialista, mostrando ante todo la modernización superficial de viejos moldes bizantinos y zaristas. Pero más interesante ha sido su crítica del Occidente capitalista, esas sociedades opulentas donde prevalecen la estulticia irradiada por los medios masivos de comunicación, el consumismo grosero, la estética de la chabacanería, el hedonismo sin un eros humano y el nihilismo de la abdicación ${ }^{75}$.

Aquí es conveniente reiterar que la corriente crítica - manifiestamente minoritaria dentro de la ensayística latinoamericana - ha estado contrapuesta a la elaboración de ideologías compensatorias de índole romántica sobre el pasado del Nuevo Mundo y de sistemas teóricos que se dedican a la exculpación de lo propio y a la incriminación de lo ajeno en lo referente a las carencias evolutivas de América Latina. Esta tendencia crítica estudia las consecuencias sociales a largo plazo de la invocación de las emociones nacionales profundas, analizando los anhelos del preconsciente colectivo que se refieren a las metas normativas últimas, aparentemente irrenunciables, que las sociedades se han fijado para dar sentido a sus esfuerzos mancomunados. Los representantes de esta corriente se han preocupado poco por tematizar la problemática del reconocimiento de las sociedades latinoamericanas en el concierto de las naciones, puesto que no postulan un contramodelo, es decir un paradigma propio y "auténtico" de desarrollo. A la hora de diseñar alternativas este impulso crítico retoma un antiguo y modesto principio de la filosofía clásica: el descubrir lo negativo constituye una pista de lo positivo, sin prefigurar su contenido.

Descontando las mencionadas tendencias críticas, tenemos en el pensamiento latinoamericano algunos dilemas centrales que permanecen vigentes hasta hoy. Las

Inventar la democracia: América Central y México, en: Octavio Paz, Pasión crítica, Barcelona: Seix Barral 1985, p. 275, 283, 293.

75 Octavio Paz, El ogro filantrópico, Barcelona: Seix Barral 1981, p. 286; Octavio Paz, Tiempo nublado, op. cit. (nota 74), pp. 17, 25, 32, 61-63. 
metas normativas de desarrollo que persiguen los movimientos políticos e intelectuales más disímiles en America Latina, expresadas en toda concisión por la ensayística, están referidas, en el fondo, a un espacio geográfico y a un horizonte de expectativas que se han originado y estructurado en el área situada entre Estados Unidos y Europa Occidental (hace pocas décadas se habría añadido la antigua Unión Soviética). Estas últimas metas evolutivas pueden ser descritas así:

(1) La construcción de un orden social basado en la modernidad científico-técnica y en el principio de rendimiento y eficacia, lo que engloba una sociedad urbana, industrializada, con alto nivel de vida y consumo y una educación determinada por reglas racionales; y

(2) la consecución de un Estado nacional fundamentado en la racionalidad instrumental, con una institucionalidad sólida (lo que engloba también una burocracia altamente eficiente), que sea reconocido y respetado en un plano de igualdad liminar en el concierto de naciones.

Estas metas históricas de largo plazo son totalmente comprensibles. Pero en última instancia carecen, como afirmó Manfred Mols, de una genuina autonomía de objetivos ${ }^{76}$. Por ello las sociedades de América Latina - y, en realidad, de todo el Tercer Mundo intentan reafirmar y consolidar aspectos autóctonos y pautas de comportamiento propias, es decir: prácticas culturales anteriores a las incursiones de la modernidad occidental, para encubrir la adopción de paradigmas evolutivos surgidos en los llamados centros metropolitanos. Esta intención, en la cual la filosofía y las diferentes manifestaciones del pensamiento juegan un rol central, trata de hacer digerible la imitación de un modelo de desarrollo que está intrínsecamente vinculado con las detestables potencias imperialistas. Constituye así el nexo afectivo entre una herencia cultural que se pierde paulatinamente y el futuro que se edifica laboriosamente. Este nexo es de gran importancia política y emotiva porque rescata elementos centrales de la propia identidad y de la infancia histórica de cada sociedad. $Y$ tiene una función de enorme relevancia socio-cultural: sugiere, a veces muy efectivamente, que la nación está construyendo un modelo propio y auténtico de desarrollo, aunque lo propio y lo auténtico se restrinja a ámbitos de actividad que pueden ser hoy calificados como secundarios, entre los cuales se encuentran los estilos políticos, el folklore y la vida familiar e íntima.

Considerando la ensayística latinoamericana como un conjunto muy diverso de concepciones socio-políticas, se puede afirmar que ha tenido desde sus comienzos una tradición consagrada a sopesar críticamente sus propios productos, dando como resultado una herencia cultural con una loable inclinación a la autocorrección y al fomento de un espíritu indagatorio, pero reproduciendo simultáneamente - en la mayoría de sus

76 Cf. el brillante ensayo que no ha perdido vigencia: Manfred Mols, Zum Problem des westlichen Vorbilds in der neueren Diskussion zur politischen Entwicklung (Sobre el problema del paradigma occidental en la nueva discusión acerca del desarrollo político), en: VERFASSUNG UND RECHT IN ÜBERSEE, vol. 8 (1975), No 1, p. 5, 11. 
exponentes - los prejuicios colectivos de un pasado autoritario.

\section{Conclusiones provisionales}

Aunque las metas normativas de evolución no hayan resultado originales, casi todas las corrientes de pensamiento en América Latina consideran la consecución de la modernidad - según moldes metropolitanos - como el camino idóneo de todo progreso histórico. La modernización es vista además como la única senda adecuada para obtener el reconocimiento de las otras naciones y sociedades en un plano de igualdad. La modernidad occidental adopta, sin embargo, un status básicamente ambiguo: es anhelada por dilatados sectores sociales y obviamente por las élites, pero al mismo tiempo es rechazada como extraña y hasta adversa con respecto a la identidad profunda de los pueblos latinoamericanos. Esta ambivalencia tiene que ver con el hecho de que el orden social moderno, fundamentado en el despliegue de la ciencia y la tecnología, por un lado, y la democracia pluralista, por otro, no constituyen realidades que se hayan originado de forma autónoma en América Latina. La construcción de la consciencia nacional permanece confrontada con los modernos valores de orientación que son apreciados positivamente $\mathrm{y}$, al mismo tiempo, rechazados como foráneos de parte de amplios sectores sociales. La aparición periódica de regímenes populistas y el florecimiento intermitente de ideologías nacionalistas e indigenistas son muestras de esa ambivalencia liminar.

En muchos países del Nuevo Mundo el resultado global puede ser calificado como una modernización imitativa que, en el campo político y en el terreno de las pautas recurrentes de comportamiento, convive desde un comienzo con una tradición autoritaria. No hay duda, y esto es también lo curioso, de que se han generado formas muy estables de simbiosis entre este legado autoritario y la modernidad técnico-económica.

La falta de reconocimiento - un fenómeno difícil de medir y hasta de describir convenientemente - promueve modelos políticos e intelectuales que a menudo denotan un regreso a raíces históricas y a herencias prerracionales que no siempre son favorables al Estado de derecho y a la democracia pluralista. En el mundo andino, por ejemplo, tendencias modernizadoras y pro-occidentales se hallan enfrentadas a programas que pretenden el retorno a un ámbito premoderno idealizado, a una Edad de Oro de solidaridad inmediata y permanente, que no sufriría las alienaciones contemporáneas y las complejidades de la vida actual. Estas últimas son consideradas como posibilidades de corrupción y engaño y como una complicación innecesaria de vínculos humanos que deberían ser directos y comprensibles, como los que se dan en los regímenes paternalistas del populismo latinoamericano. Se trata, probablemente, de ideologías 
compensatorias que creen ver la solución de estos dilemas en el retorno a elementos irracional-románticos de vieja data como el populismo ${ }^{77}$. A la larga estos modelos y estas ideologías impiden el desarrollo de la democracia liberal pluralista de corte occidental, la cual, frente a la amplia experiencia histórica de las últimas décadas, ha demostrado ser el mal menor en la esfera de la construcción de modelos de convivencia razonable de los seres humanos. En efecto: la seguridad jurídica, la igualdad ante la ley, la separación de poderes y la protección de los derechos civiles representan elementos y valores irrenunciables en la compleja vida social de la actualidad, y ellos no han sido factores constituyentes ni de las herencias precolombinas, ni de las tradiciones ibero-católicas y tampoco de la praxis populista contemporánea. La dignidad rescatable del orden moderno se halla en aquella concepción de la política que la define como una deliberación permanente y una búsqueda incesante de soluciones racionales y razonables de carácter provisional; esa dignidad se complementa con un interés emancipatorio que está por encima de los valores particulares, por más enraizados que estos se encuentren en tradiciones venerables compartidas por dilatados sectores populares.

77 Fareed Zakaria, The Future of Freedom: Illiberal Democracy at Home and Abroad, New York: Norton 2003, passim. 